\title{
Wind events and benthic-pelagic coupling in a shallow subtropical bay in Florida
}

\author{
David Lawrence ${ }^{1}$, Michael J. Dagg ${ }^{1, *}$, Hongbin Liu ${ }^{1}$, Shailer R. Cummings ${ }^{2}$, \\ Peter B. Ortner ${ }^{2}$, Christopher Kelble ${ }^{3}$ \\ ${ }^{1}$ Louisiana Universities Marine Consortium, 8124 Highway 56, Chauvin, Louisiana 70344, USA \\ ${ }^{2}$ Atlantic Oceanographic and Meteorological Laboratory, 4301 Rickenbacker Causeway, Miami, Florida 33149, USA \\ ${ }^{3}$ Cooperative Institute of Marine and Atmospheric Studies, Rosenstiel School of Marine and Atmospheric Science, \\ University of Miami, 4600 Rickenbacker Causeway, Miami, Florida 33149, USA
}

\begin{abstract}
During the winter months (December to April), the SE United States is influenced by continental air masses from the north or northwest which pass at approximately 4 to $7 \mathrm{~d}$ intervals. These wind events can cause suspension of bottom sediments in Florida Bay. Over a $9 \mathrm{~d}$ period in March 2001, we examined the effects of a wind-mixing event on the pelagic system within the NW part of Florida Bay, where water depth is 2 to $3 \mathrm{~m}$. This event caused significant suspension of bottom materials, large increases in $\mathrm{NH}_{4}$ and $\mathrm{PO}_{4}$, smaller increases in $\mathrm{NO}_{3}+\mathrm{NO}_{2}$ and $\mathrm{Si}(\mathrm{OH})_{4}$, a decrease in microzooplankton abundance, and an increase in benthic copepods in the water column. As wind speeds declined, there was a rapid decline in $\mathrm{PO}_{4}$ concentration, gradual declines in suspended sediment, $\mathrm{NH}_{4}$ and $\mathrm{Si}(\mathrm{OH})_{4}$, an increase in chlorophyll a (chl a) stock, an increase in phytoplankton growth and productivity, an increase in microzooplankton grazing rate, and a settling of the benthic harpacticoid community. No grazing response was apparent in the mesozooplankton community. The wind event clearly injected dissolved and particulate benthic materials into the water column, where they directly stimulated the bacterioplankton, phytoplankton and microzooplankton communities within 1 to $2 \mathrm{~d}$ after the event. The water column was strongly net heterotrophic at this time, suggesting a large input of dissolved organic matter from the bottom. Stimulation of the pelagic food web continued at least until we completed our study $6 \mathrm{~d}$ after the event. By the end of our study, the water column was net autotrophic.
\end{abstract}

KEY WORDS: Benthic-pelagic coupling - Suspended sediments - Nutrients - Phytoplankon · Microzooplankton grazing $\cdot$ Mesozooplankton grazing $\cdot$ Net heterotrophy $\cdot$ Florida Bay

\section{INTRODUCTION}

Energy and material cycling in shallow aquatic systems are partially dependent on exchanges between the benthic and pelagic environments (Marcos \& Boero 1998). In the classical coupling scenario, nutrients, benthic phytoplankton and other dissolved and particulate organic materials produced in situ in the benthos are delivered via diffusion or mixing to the water column, where they are utilized by bacteria and phytoplankton, thereby stimulating the pelagic food web. In turn, some of the organic matter from the pelagic food web sinks to the bottom, where it stimulates the ben- thic food web. The degree of benthic-pelagic coupling is affected by the depth of the water column and by the frequency and magnitude of storms or other wind events that enhance vertical mixing (Fanning et al. 1982, Dagg 1988, Nielson \& Kiørboe 1991, Kiørboe 1993). Such events have been shown to enhance nutrient availability by desorption from suspended sediment particles (Stumm \& Leckie 1971, Nixon 1981, Fanning et al. 1982, Hansen et al. 1997) and by directly mixing nutrient-rich porewater into the water column (Morin \& Morse 1999, Warnken et al. 2000). Pelagic environments that do not have major sources of external nutrients will have a stronger response to an injec- 
tion of dissolved or particulate material from the benthos than environments such as eutrophic estuaries, which are affected by nutrient-rich rivers (Kelly et al. 1985).

In addition to increasing concentrations of pelagic nutrients, events leading to increased concentrations of suspended sediments reduce light availability. Under these circumstances, the response of pelagic phytoplankton to a mixing event may be delayed until sediment particles settle and light conditions improve.

Changes in phytoplankton or bacterioplankton growth and biomass resulting from wind-induced mixing events may have effects on the microzooplankton and mesozooplankton communities. Populations of herbivorous protists are able to rapidly respond to increases in phytoplankton growth because of their short generation times (Franks 2001). Although larger zooplankton such as copepods cannot numerically respond as quickly, they can functionally respond to increases in phytoplankton stock by a near-instantaneous increase of ingestion rate (Frost 1972, Dagg 1983), which could quickly translate to an enhancement of reproductive output (Dagg 1988). Furthermore, if mixing events occur regularly, the composition of the phytoplankton community may change (Kiørboe 1993), which may impact the composition of the grazing community (Hansen 1992, Kiørboe 1993). The responses of phytoplankton-zooplankton dynamics to such short-term events are not well understood.

One of the challenges associated with understanding benthic-pelagic coupling is obtaining information on the short timescales at which mixing events occur. In this paper, we describe changes in water-column properties (suspended particulate materials, chlorophyll a (chl a), light, dissolved nutrients, microzooplankton and mesozooplankton) and processes (phytoplankton production and growth, respiration, and microzooplankton and mesozooplankton grazing) during a strong mixing event in a subtropical coastal marine environment, Florida Bay, USA. We expected that mixing would inject bottom sediments and dissolved nutrients into the water column and, after sediments had resettled, nutrients would stimulate the phytoplankton and consumer portions of the food web.

\section{MATERIALS AND METHODS}

Study site. Florida Bay is a shallow ( $<4 \mathrm{~m}$ depth) $1500 \mathrm{~km}^{2}$ subtropical estuary bordered by the Gulf of Mexico to the west, the Everglades to the north, and the Florida Keys (Fig. 1). The bay has a network of submerged mud banks and small islands which reduce internal water exchange, and the Florida Keys dampen tidal influence from the Atlantic Ocean. Reduced water flow within the bay results in horizontal isolation of water masses and in reduced vertical mixing (Wang et al. 1994). The bay has been divided into 4 major regions based on physical and biological properties: north central, south central, eastern and western (Phlips et al. 1995). There is great variability among regions. For example, in one study (Phlips \& Badylak 1996), chl a concentrations averaged nearly $20 \mu g \mathrm{l}^{-1}$ in the north central region, but $<2 \mu \mathrm{g} \mathrm{l}^{-1}$ in the eastern region. Blooms of cyanobacteria are common in the north central region, whereas blooms of diatoms are frequent in the western region, which is open to the Gulf of Mexico. Our study was done at 5 stations in the western region, in waters of approximately 2 to $3 \mathrm{~m}$ depth (Fig. 1).

There is strong seasonality to wind patterns in south Florida. During the winter months (December to April), continental air masses from the north or northwest pass over the region at approximately 4 to $7 \mathrm{~d}$ intervals (Wang 1998). Typically, each event lasts several days and is associated with initial strong north or NW winds which gradually weaken over the next few days. These events are usually preceded by winds with a strong southerly component. The passage of continental air masses often results in episodes of sediment suspension in Florida Bay (Phlips et al. 1995). During other months, winds are more uniformly from the south or southwest and, apart from storms, are not as strong as during winter.

Methods. Data on wind speed and wind direction were collected by a COMPS (Coastal Ocean Monitoring and Prediction System) monitoring station (Latitude $25^{\circ} 05.061^{\prime} \mathrm{N}$, Longitude $81^{\circ} 05.744^{\prime} \mathrm{W}$; http://

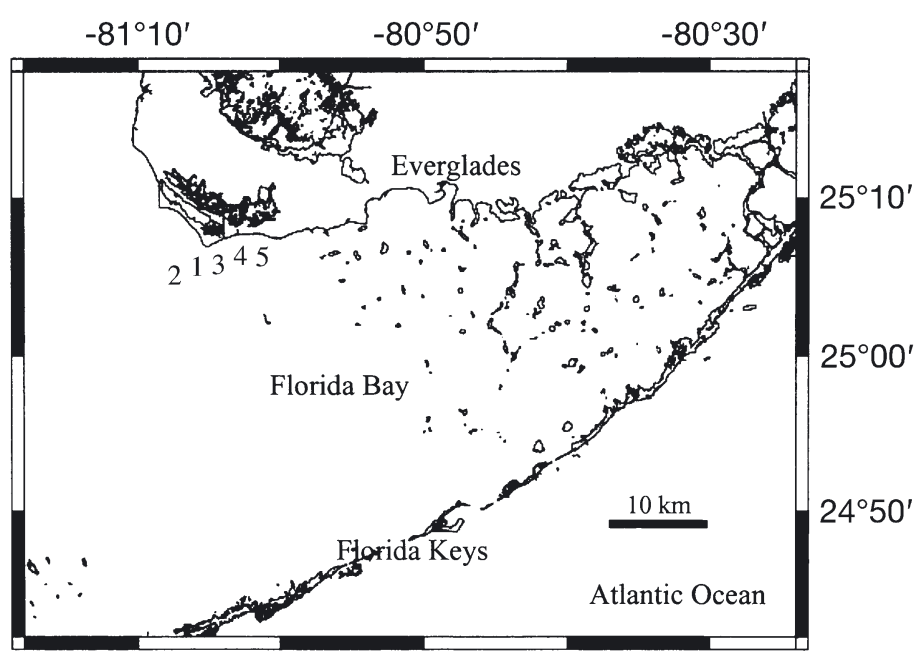

Fig. 1. Florida Bay, USA, showing location of stations in the NW portion of bay: Stn 1 corresponds to COMPS (Coastal Ocean Monitoring and Prediction System) station. Stn 5 is our primary study site 
comps.marine.usf.edu/nfb/index.shtml) maintained by the University of South Florida and located at Stn 1, approximately $8.4 \mathrm{~km}$ west of our primary study site, Stn 5 (Fig. 1). Wind speed and direction (R. M. Young Model 05103) were recorded every 6 min.

Our primary study site was located at $25^{\circ} 07.03^{\prime} \mathrm{N}$, $81^{\circ} 01.22^{\prime} \mathrm{W}$ (Stn 5 in Fig. 1). Water depth at this site was about $2.2 \mathrm{~m}$. Water was collected daily from 5 to 13 March 2001 and returned to a shore-based laboratory within $30 \mathrm{~min}$ to determine concentrations of suspended particulate material (SPM), dissolved nutrients, and chl a. We used 2 hand-lowered 201 carboys to collect sufficient water from the surface for all analyses and for the incubation experiments described below. For each SPM measurement, a known volume of water was filtered onto a pre-weighed Whatman $47 \mathrm{~mm}$ GF/F filter, rinsed with freshwater and dried at $60^{\circ} \mathrm{C}$. The filter was again weighed and the amount of SPM on the filter was calculated by subtracting the blank filter weight. Samples for nutrient analyses were filtered though $0.2 \mu \mathrm{m}$ Millex-GS filters and frozen, except for ammonia samples, which were preserved with a drop of chloroform and refrigerated (Zhang et al. 1997a). Nutrient analyses were made with an Alpkem gas-segmented continuous-flow autoanalyzer (Zhang \& Berberian 1997a, Zhang et al. 1997a,b, 1999). Chl a concentrations were measured after extraction for several hours in the dark at $4^{\circ} \mathrm{C}$ in a solution of acetone:DMSO (60:40) using standard fluorometric methods (Shoef \& Lium 1976).

At our primary station, vertical profiles of SPM, chl $a$ and nutrients were determined on 7, 9, and 11 March 2001. Water for vertical profiles was collected from depths of $0.2,0.5,1.3$, and $2.1 \mathrm{~m}$ using a 11 water sampler (Lamotte) closed with a messenger.

The absorption of light with depth was measured at approximately noon each day with a $4-\pi$ photosynthetically active radiation, PAR (400 to $700 \mathrm{~nm}$ ) quantum light meter (Licor Model LI-188B). Readings were made every $0.25 \mathrm{~m}$ from the surface to the depth at which light was no longer detectable with this instrument.

A 5-station (Fig. 1) spatial survey of the surface concentrations of SPM, chl a and nutrients was conducted on 8 March during a period of high wind and on 13 March during a period of relative calm.

Community respiration and production were measured daily by the oxygen method (Strickland \& Parsons 1972, Friederich et al. 1991). An incubator raft of 6 clear acrylic cylinders was used for in situ incubation of oxygen productivity flasks at different light intensities. Teflon-stoppered KiMAX Oxygen flasks were used as incubation vessels. For each experiment, a surfacewater sample was taken with a $20 \mathrm{l}$ plastic bucket; 3 replicate, time-zero subsamples were immediately taken, fixed with $\mathrm{MnCl}_{3}$ and $\mathrm{NaIO}_{3}$, and set aside for later titration; 6 triplicate sets of flasks were placed inside the incubator cylinders at light levels of 100, 50, $29,15,3 \%$ and zero. The array, with a 21 polycarbonate bottle at each corner for flotation, was tied to an anchored float at our station site. Bottle incubation depth was $0.2 \mathrm{~m}$. Incubation period was centered around mid-day and ranged from 6 to $8.5 \mathrm{~h}$. The array was recovered at the end of the incubation period, and flask contents were immediately fixed. Later, in the laboratory, oxygen concentration was determined by a modified Winkler method. Gross production $\left(P_{\mathrm{g}}\right)$ in each light bottle was determined by:

$$
P_{\mathrm{g}}\left(\mu \mathrm{M} \mathrm{O}_{2} \mathrm{l}^{-1} \mathrm{~h}^{-1}\right)=\frac{\left(\mathrm{O}_{\mathrm{LB}}-\mathrm{O}_{\mathrm{DB}}\right)}{\text { incubation time }(\mathrm{h})}
$$

where $\mathrm{O}_{\mathrm{LB}}$ is the final oxygen concentration in the light bottle and $\mathrm{O}_{\mathrm{DB}}$ is the final oxygen concentration in the dark bottle. Net daily production $\left(P_{\mathrm{n}}\right)$ was determined by first calculating the total gross production over the daylight period, determined as the number of hours between sunrise and sunset minus $1.5 \mathrm{~h}$, then subtracting the community respiration over $24 \mathrm{~h}$. Community respiration $(R)$ was determined by:

$$
R\left(\mu \mathrm{M} \mathrm{O}_{2} \mathrm{l}^{-1} \mathrm{~d}^{-1}\right)=\frac{\left(\mathrm{O}_{\mathrm{IB}}-\mathrm{O}_{\mathrm{DB}}\right)}{\text { incubation time }(\mathrm{h})} \times 24
$$

where $\mathrm{O}_{\mathrm{IB}}$ is the initial oxygen concentration in the bottles.

Zooplankton grazing experiments were conducted daily from 5 to 12 March, except for 8 March. Each experiment included 2 components: a dilution experiment (Landry \& Hasset 1982) to measure growth rate of phytoplankton and grazing rate of microzooplankton (organisms $<200 \mu \mathrm{m}$ ), and a mesozooplankton addition experiment (Lehman 1980, Calbet \& Landry 1999) to measure the grazing impact of the mesozooplankton community (organisms $>200 \mu \mathrm{m}$ ) on phytoplankton. Water for grazing experiments was collected from the study site in acid-washed 201 carboys. Once filled, carboys were placed in black plastic and transported to the laboratory within $30 \mathrm{~min}$. For the dilution component, duplicates of whole natural water and of $0.25,0.50$, and 0.75 natural seawater:filtered seawater mixtures were prepared in 1.21 polycarbonate bottles. Filtered seawater was obtained by gravity flow through an in-line filter capsule $(0.2 \mu \mathrm{m}$, acid-soaked and thoroughly rinsed with seawater) into a clean polycarbonate carboy. Whole seawater was introduced into experimental bottles via silicone tubing with a $200 \mu \mathrm{m}$ Nitex mesh attached at the end to exclude mesozooplankton. Nutrients (final concentrations of $12 \mu \mathrm{M} \mathrm{NO}{ }_{3}, 1.2 \mu \mathrm{M} \mathrm{PO}_{4}$, and $\left.12 \mu \mathrm{M} \mathrm{Si}(\mathrm{OH})_{4}\right)$ were added to each bottle to promote uniform growth of 
phytoplankton. We filled 2 bottles with undiluted natural seawater without added nutrients to determine the effects of nutrient enrichment on phytoplankton growth. A $200 \mathrm{ml}$ sample of whole water was preserved in Lugol's solution for later microscopic analysis of the initial community composition. Microzooplankton were identified by settling duplicate $40 \mathrm{ml}$ aliquots from each sample. Counts were performed at $20 \times$ on an Olympus IM inverted microscope.

Mesozooplankton were collected by horizontally towing a $0.75 \mathrm{~m}$ diameter $202 \mu \mathrm{m}$ mesh plankton net fitted with a General Oceanics flowmeter. Collected animals were carefully poured into an insulated container and returned to the laboratory. Only freeswimming and healthy organisms that passed upwards through a submerged $2000 \mu \mathrm{m}$ mesh sieve were used in the experiments. For each experiment, a range of grazing rates was established by adding aliquots of 3 different concentrations of mesozooplankton to 1.21 bottles containing natural seawater. Each treatment was duplicated. This method (Lehman 1980, Calbet \& Landry 1999) allows the grazing rate of the entire mesozooplankton community to be determined without sorting individual species for incubations. Nutrients were added to the mesozooplankton bottles at the same concentrations as the dilution bottles. Control bottles without mesozooplankton were shared with the dilution experiments. An identical set of mesozooplankton aliquots was taken to determine the biomass, as dry weight, added to each experimental bottle. Dry weight samples were filtered onto pre-weighed Whatman GF/F $47 \mathrm{~mm}$ filters, rinsed with freshwater to remove salt, and dried at $60^{\circ} \mathrm{C}$. All remaining mesozooplankton were preserved in 5\% formalin for later determination of ambient mesozooplankton concentration. After setup, experimental bottles were returned to the study site and incubated in situ for $24 \mathrm{~h}$ in a clear Plexiglas raft, maintaining all bottles horizontally at $0.2 \mathrm{~m}$ depth.

Changes in chl a concentration were used to calculate grazing and phytoplankton growth rates in each experiment. Chl a concentrations were determined for initial whole water (triplicates) and for each bottle at the end of incubation (duplicates). At the conclusion of the experiment, mesozooplankton from each treatment were retained by filtration through a $100 \mu \mathrm{m}$ sieve. In the dilution component of each experiment, the rate of phytoplankton growth under nutrient-enriched conditions $\left(\mu_{n}\right)$ and the rate of phytoplankton mortality due to microzooplankton grazing were obtained by linear regression of net growth rate against dilution factor. An estimate of phytoplankton growth in water with ambient nutrients $\left(\mu_{0}\right)$ was calculated by adding the mortality estimate to the net growth rate of phytoplankton in the bottles that contained unamended natural seawater. Mesozooplankton grazing rate was obtained by linear regression of net growth rate of phytoplankton against biomass (mg dry wt $\mathrm{l}^{-1}$ ) of mesozooplankton added to each treatment. The decrease in phytoplankton growth rate per unit of zooplankton biomass $\left(\mathrm{d}^{-1} \mathrm{mg}\right.$ dry wt $\left.\mathrm{l}^{-1}\right)$ was multiplied by the ambient zooplankton biomass (mg dry wt $\mathrm{l}^{-1}$ ) to obtain the community grazing rate at natural zooplankton concentration $\left(\mathrm{d}^{-1}\right)$.

Mesozooplankton samples were counted using a compound microscope to determine natural concentrations of individual species. Aliquots (generally 1/8 or 1/16 of the sample split with a Folsom Plankton Splitter) were analyzed such that approximately 1000 individuals were identified and counted.

\section{RESULTS}

During 2001, water temperature at the COMPS monitoring station (Stn 1 in Fig. 1) ranged between $14.1^{\circ} \mathrm{C}$ in January and $32.4^{\circ} \mathrm{C}$ in August. During our study,
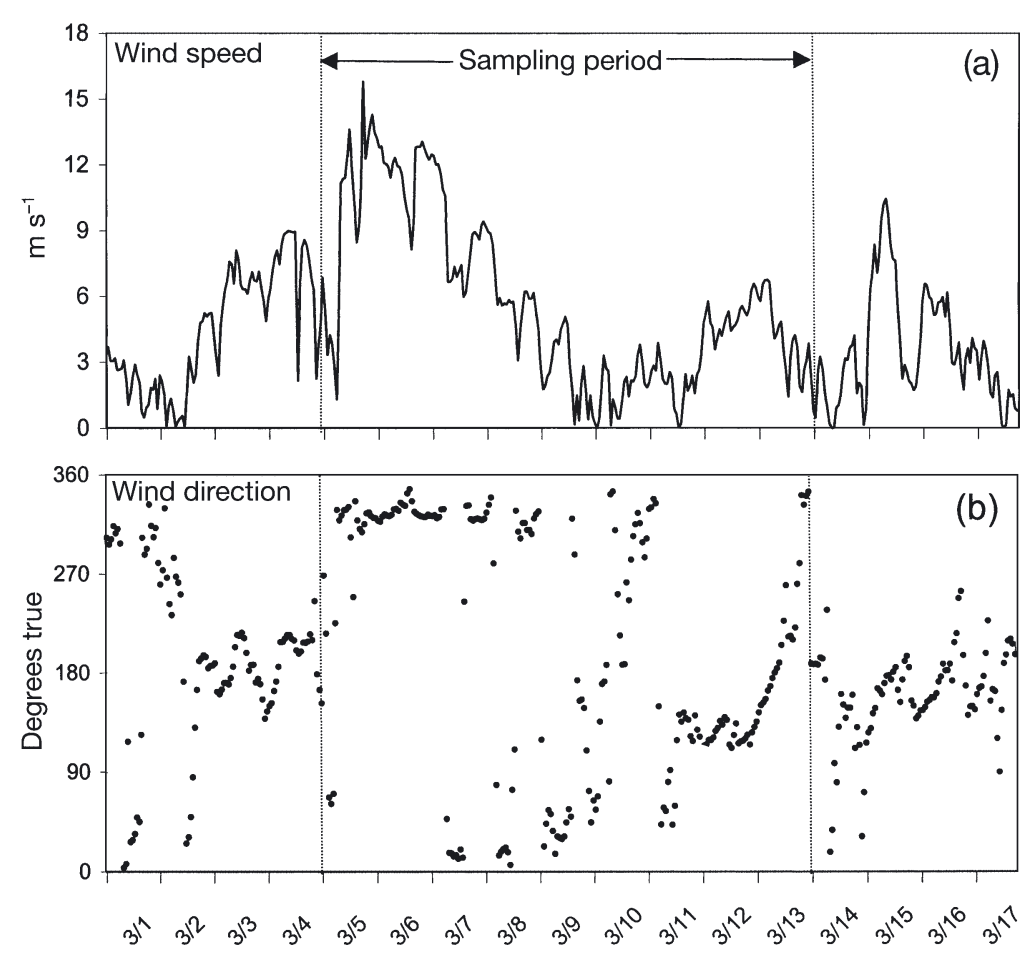

Fig. 2. (a) Wind speed and (b) wind direction at COMPS monitoring station from 1 to 17 March 2001. Data are hourly averages 

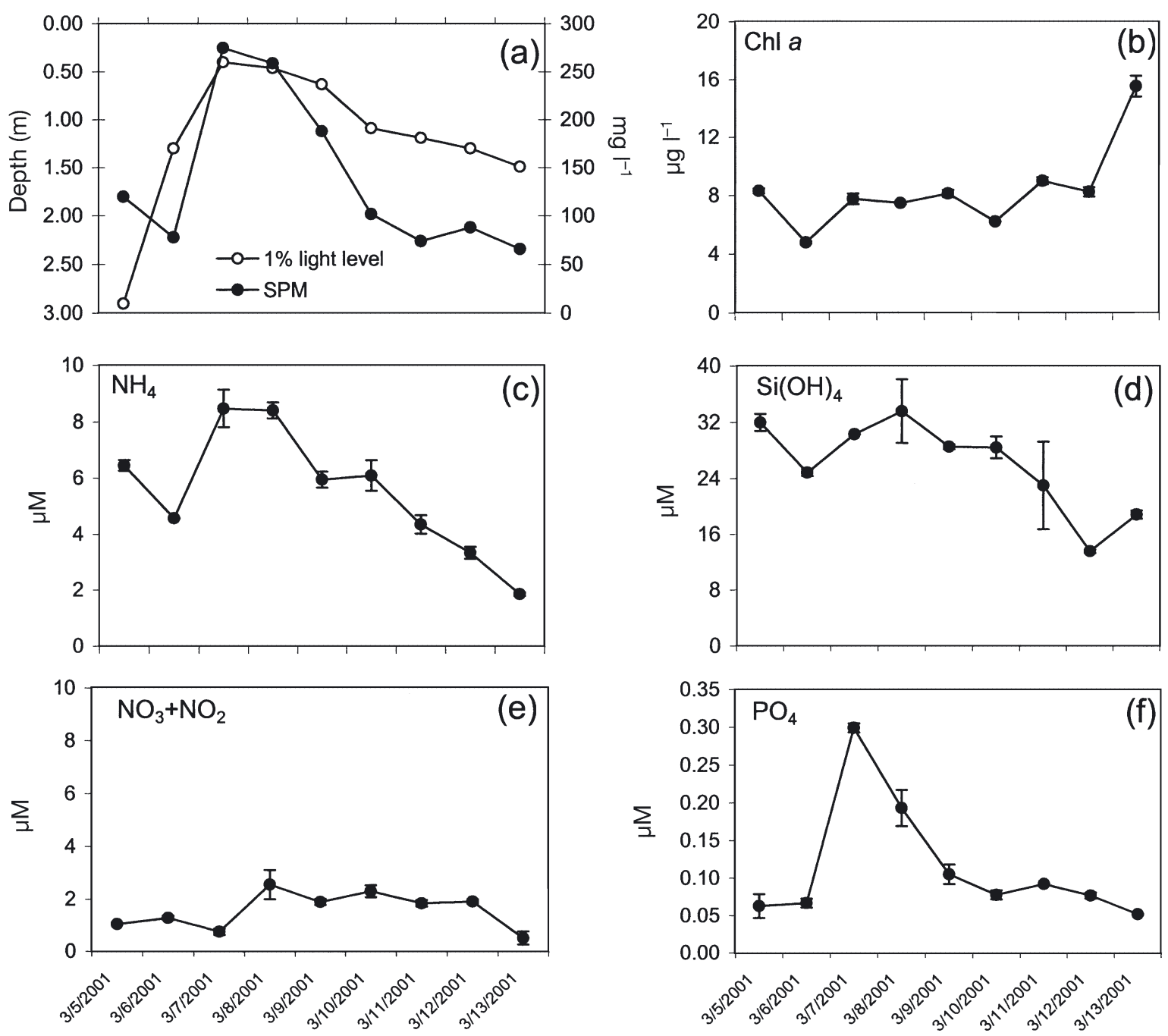

Fig. 3. Water properties at our primary station, Stn 5. (a) Concentration of suspended particulate material (SPM) and depth of $1 \%$ light level; (b) chl a concentration; (c-f) dissolved nutrient concentrations. Error bars $= \pm \mathrm{SE}$. Dates are $\mathrm{mo} / \mathrm{d} / \mathrm{yr}$

water temperature was between 25 and $26^{\circ} \mathrm{C}$ at this location.

On the days prior to our study (2 to 4 March 2001), wind was from the south at speeds of about 6 to $8 \mathrm{~m} \mathrm{~s}^{-1}$ (Fig. 2). On 5 March, as our study began, wind shifted to north or northwesterly, and the maximum speeds observed during our study (about $15 \mathrm{~m} \mathrm{~s}^{-1}$ ) were on 5 and 6 March. Wind speed declined from 7 to 10 March, then increased slightly near the end of our study on 13 March. Wind remained north and northeasterly from 5 to 10 March, then shifted to more easterly and southerly (Fig. 2b).

Concentrations of suspended sediments, chl $a$, and nutrients were homogenous on the 3 dates examined (7, 9, and 11 March), so surface measurements are assumed to be representative of the water column throughout this study, with the possible exception of
5 March (see below). Surface concentration of SPM at our primary station, Stn 5, increased in response to the wind event, from about $100 \mathrm{mg} \mathrm{l}^{-1}$ on 5 and 6 March to $>250 \mathrm{mg} \mathrm{l}^{-1}$ on 7 and 8 March (Fig. 3a). SPM concentrations then declined to pre-event levels as wind speeds decreased (Fig. 3a).

At our primary station, light penetration was negatively related to SPM concentration (Fig. 3a). Coincident with the highest SPM loads on 7 and 8 March, light penetration was minimal (Fig. 3a), and then generally increased thereafter as SPM concentration declined. Excluding 5 March, the $1 \%$ light depth was closely correlated to the concentration of SPM $\left(\mathrm{r}^{2}=\right.$ 0.92). March 5 was excluded because it appeared that SPM was not uniformly distributed throughout the water column on that date. Only on this date did the extinction coefficient $(K)$ increase uniformly with 

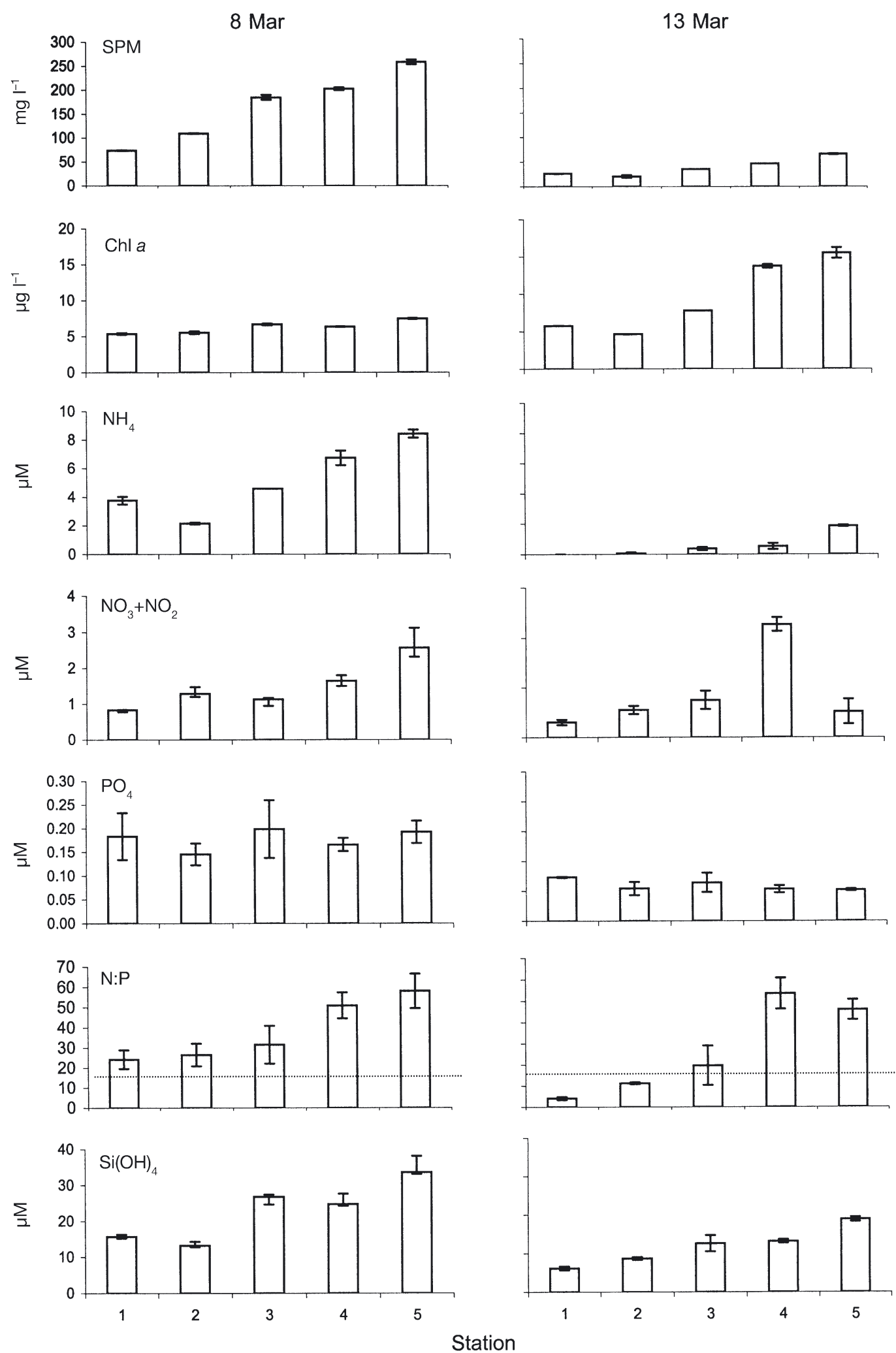

Fig. 4. Spatial distribution of suspended particulate material (SPM), chl $a$, dissolved nutrient concentrations, and N:P ratio on 8 and 13 March 2001. Dotted line through N:P ratios represents Redfield ratio (16:1). Stn 1 corresponds to COMPS weather station. Stn 5 is primary study site. Error bars $= \pm \mathrm{SE}$ 
Table 1 . Increase in phytoplankton growth rate, $\left(\mu_{\mathrm{n}}-\mu_{0}\right) / \mu_{0}$ (where $\mu_{\mathrm{n}}$ and $\mu_{0}=$ growth under nutrient-enriched and ambient conditions, respectively), in whole water observed after addition of nutrients. nd: no data

\begin{tabular}{|lc|}
\hline Date (2001) & Increase in $\mu$ \\
\hline $5 \mathrm{Mar}$ & 1.60 \\
$6 \mathrm{Mar}$ & 1.14 \\
$7 \mathrm{Mar}$ & 1.24 \\
$8 \mathrm{Mar}$ & $\mathrm{nd}$ \\
$9 \mathrm{Mar}$ & 1.18 \\
$10 \mathrm{Mar}$ & 1.25 \\
$11 \mathrm{Mar}$ & 1.34 \\
$12 \mathrm{Mar}$ & 1.29 \\
$13 \mathrm{Mar}$ & $\mathrm{nd}$ \\
& \\
\hline
\end{tabular}

depth, from $0.89 \mathrm{~m}^{-1}$ in the upper $0.25 \mathrm{~m}$ to $2.24 \mathrm{~m}^{-1}$ between the deepest light measurements at 1.00 and $1.25 \mathrm{~m}$. Similar analyses on all other dates did not show any patterns of $K$ versus depth.

Nutrient concentrations at our study site also responded to the wind event. Concentrations of $\mathrm{NH}_{4}$ and $\mathrm{PO}_{4}$ were highest on 7 and 8 March (Fig. 3c,f), the period of highest SPM concentration, and declined thereafter. $\mathrm{PO}_{4}$ concentration declined rapidly, returning nearly to pre-event concentrations within $3 \mathrm{~d}$, whereas $\mathrm{NH}_{4}$ concentration declined slowly and continuously during the remaining $6 \mathrm{~d}$ of our study. Concentrations of $\mathrm{Si}(\mathrm{OH})_{4}$ and $\mathrm{NO}_{3}+\mathrm{NO}_{2}$ (Fig. 3d,e) did not show as strong a response to the wind event as $\mathrm{NH}_{4}$ and $\mathrm{PO}_{4}$, although both were highest on 8 March and $\mathrm{Si}(\mathrm{OH})_{4}$ concentrations tended to decline during the remainder of the study. Concentrations of all 4 nutrients were highest on either 7 or $8 \mathrm{March}$, the days immediately following the highest wind speed and the days of highest SPM concentration.

The concentration of extracted chl a did not show an immediate increase in response to the wind event, but instead was highest towards the end of the study period, on 13 March (Fig. 3b).

On 2 occasions, we did a small-scale spatial survey of surface waters (Fig. 4). Surface samples were taken at all 5 stations (Fig. 1) on 8 March, representing the period of highest SPM and nutrients at our primary station, and on 13 March, representing the period of lowest SPM and nutrient concentrations and highest chl $a$ concentrations: 2 patterns emerged. First, there was a tendency for concentrations of SPM, chl $a, \mathrm{NH}_{4}$, $\mathrm{NO}_{3}+\mathrm{NO}_{2}$ and $\mathrm{Si}(\mathrm{OH})_{4}$ to increase in a west-to-east direction, with highest values at our primary station. Second, the temporal pattern observed at our primary station was seen over the entire region covered by the surveys; concentrations of $\mathrm{SPM}, \mathrm{NH}_{4}, \mathrm{PO}_{4}, \mathrm{NO}_{3}+\mathrm{NO}_{2}$, and $\mathrm{Si}(\mathrm{OH})_{4}$ were generally lower at all 5 stations on 13 March than on 8 March, and chl a concentrations were higher. This indicates that the temporal patterns observed at our primary station were representative of changes occurring over a wider spatial area.

A comparison of the growth of phytoplankton in the nutrient-enriched treatments of our incubation experiments with rates in the non-enriched controls provided an estimate of the degree of nutrient limitation on growth (Table 1). The measurement made on 5 March, prior to the wind event, indicated a $60 \%$ enhancement, suggesting limitation at this time. Although there was some apparent enhancement associated with nutrient additions on all days following initiation of the wind event (Table 1), there was no significant difference between the degree of limitation on 6 and 7 March compared to 9 to 12 March (unpaired $t$-test, $\mathrm{p}=0.27$ ). With the exception of 5 March, nutrient limitation did not appear to be a major factor in determining growth rates. This was also observed in our dilution experiments, where phytoplankton growth rate $\left(\mu \mathrm{d}^{-1}\right)$ was high on all days except 7 March (Fig. 5a). We attribute the lower growth rate on 7 March to significantly lower light availability at the incubation depth $(20 \mathrm{~cm})$, as
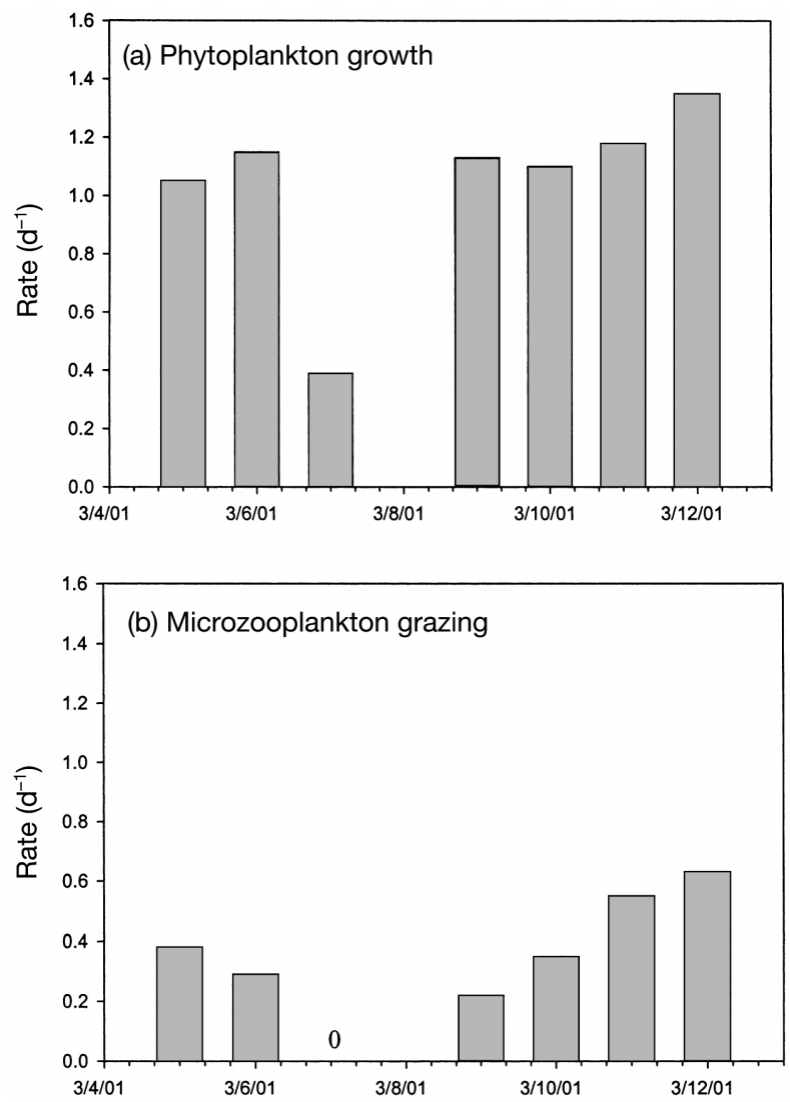

Fig. 5. Phytoplankton growth rates (a) and microzooplankton grazing rates (b) derived from incubation experiments during study period. All incubations were at $0.20 \mathrm{~m}$ depth. No experiment was performed on $8 \mathrm{March}$ 


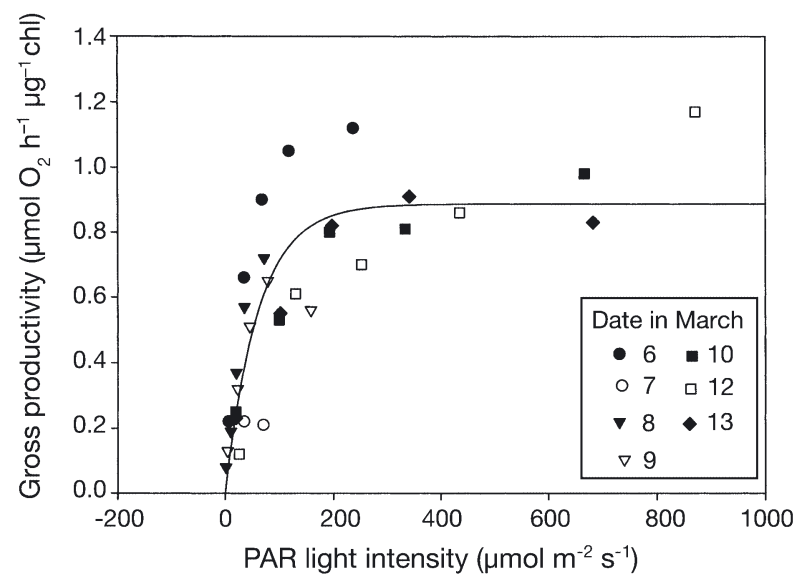

Fig. 6. Relationship between gross productivity per unit chl a and light intensity during study period. Curve (Platt et al. $1980)$ is described by $y=0.8874\left(1-\mathrm{e}^{-0.0143 \times / 0.8874}\right), \mathrm{r}^{2}=0.71$

this was the date of the highest extinction coefficient and highest SPM concentration (Fig. 3a).

The relationships between gross productivity $\left(P_{g}, \mu m o l O_{2} \mathrm{~h}^{-1} \mu \mathrm{g}^{-1} \mathrm{chl}\right.$ a) and light intensity $(I, \mu \mathrm{mol}$ $\mathrm{m}^{-2} \mathrm{~s}^{-1}$ ) further suggest the lack of nutrient limitation from 6 to 13 March (Fig. 6). All $P_{\mathrm{g}}$ versus I relationships were similar and can be reasonably fitted with a single curve, suggesting that nutrients were not affecting this relationship during our study. This relationship (Fig. 6) also indicates that light at $20 \mathrm{~cm}$ on 7 March $(76 \mu \mathrm{mol}$ $\mathrm{m}^{-2} \mathrm{~s}^{-1}$ ) would be severely limiting.

For each day of our study, the $P_{\mathrm{g}}$ versus $I$ relationship (Fig. 6), the light profile, and the chl a concentration were used to determine the depth-integrated gross productivity (Fig. 7). Lowest values were observed on 7 and 8 March, and highest values occurred at the end of our study period, on 12 and 13

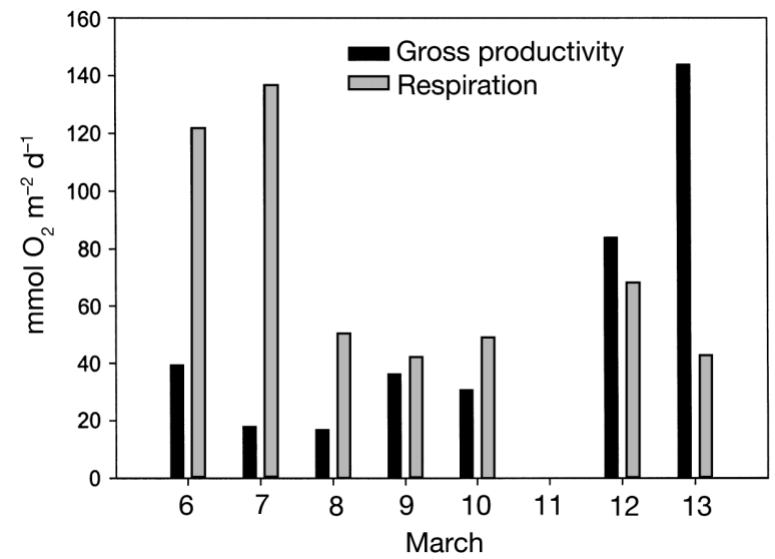

Fig. 7. Gross productivity and respiration $\left(\mathrm{m}^{-2} \mathrm{~d}^{-1}\right)$ during each incubation experiment
March. A water-column respiration rate was also calculated for each day by assuming respiration is uniform with depth. Respiration was approximately twice as high on 6 and 7 March as on other days, and greatly exceeded gross production on these days. On 9 and 10 March, gross production and respiration were approximately equal, and on the remaining days gross productivity exceeded respiration. Thus, the water column on 6 and 7 March was strongly net heterotrophic, was slightly net heterotrophic during the mid-portion of our study, and net autotrophic on 12 and 13 March (Fig. 7). This pattern is consistent with the increase in chl a stock observed on the last day at our primary station (Fig. 3b).

Microzooplankton grazing rate $\left(\mathrm{g} \mathrm{d}^{-1}\right)$ derived from the dilution experiments was between 0.25 and $0.30 \mathrm{~d}^{-1}$ on 5 and 6 March, undetectable on 7 March when the wind event was strongest, and then almost tripled from 9 to $12 \mathrm{March}$, increasing from $0.22 \mathrm{~d}^{-1}$ to $0.63 \mathrm{~d}^{-1}$ during this $4 \mathrm{~d}$ period (Fig. 5b). On all days, $g<\mu$ in our incubations (Fig. 5). Microzooplankton abundance dramatically declined in the days immediately following the wind event on 5 March (Fig. 8). This decline was mostly the result of a decrease in the number of ciliates, the dominant component of the microzooplankton community at the onset of the event. Ciliate concentration was 8.32 cells $\mathrm{ml}^{-1}$ on 5 March, but only 1.57 cells $\mathrm{ml}^{-1}$ on 7 March. Conversely, thecate dinoflagellates increased in abundance during our study, beginning at 0.08 cells $\mathrm{ml}^{-1}$ on 5 March, increasing to $2.61 \mathrm{cells} \mathrm{ml}^{-1}$ on $12 \mathrm{March}$, and comprising $66 \%$ of the total microzooplankton community on 13 March. The increase in microzooplankton grazing rate (Fig. 5b) from 9 to 12 March was greater than the increase in abundance of grazers over the same time, indicating additional factors affecting grazer-phytoplankton interactions.

Homogeneity of the water column suggests that it is possible to extrapolate the growth and grazing rates measured at a single depth in dilution experiments to water-column rates of growth and grazing. For grazing, the simplest assumption is uniformity with depth, and the rate measured in each dilution experiment at $20 \mathrm{~cm}$ is assumed to be the same at all depths in the $2 \mathrm{~m}$ water column. For phytoplankton growth, a reasonable assumption is that it is related to light in a similar fashion to gross productivity (Fig. 6), and we therefore fitted the growth rates from the dilution experiments to the light level at $20 \mathrm{~cm}$ on each day. This equation $\left(y=1.210\left(1-\mathrm{e}^{-0.0092 x}\right), \mathrm{r}^{2}=\right.$ 0.77 ) allows the growth at any depth (light level) to be calculated. The net growth coefficient $(\mu-g)$ was calculated for the water column (Table 2). Apart from 5 March, the day prior to the wind event, net rates are all close to 0 , i.e. between -0.09 and +0.17 . At 


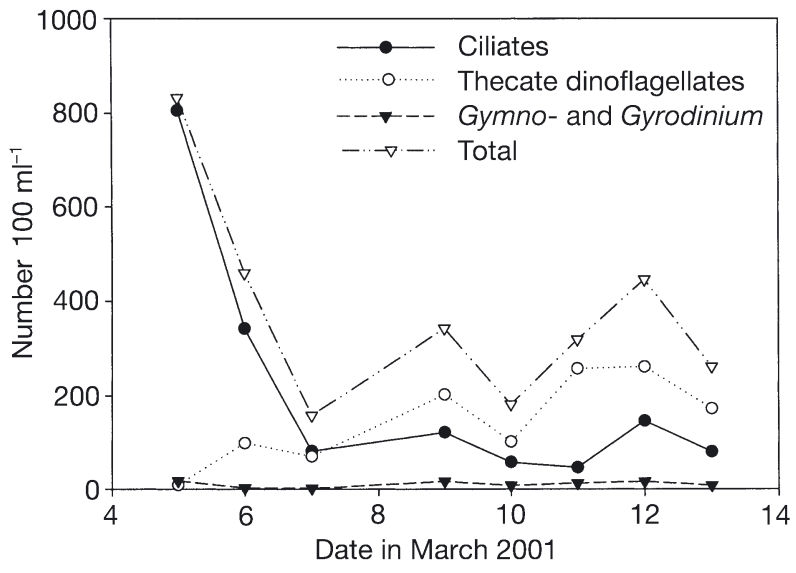

Fig. 8. Abundance of major groups of microzooplankton during study period

these rates, the chl a stock would not be expected to change much over time. This is generally consistent with our observations (Fig. 3b), except for the observed increase in chl a on the last day of our observations, 13 March.

Grazing by the mesozooplankton community comprised only a small fraction of the total grazing, being generally about 2 orders of magnitude smaller than the microzooplankton grazing (data not shown). There was no apparent response by the mesozooplankton in terms of grazing or in terms of total population size. However, the composition of the mesozooplankton community was affected by the wind event. Prior to the event, the population was dominated by pelagic species, primarily copepodid stages of Acartia tonsa. Immediately after the event, benthic harpacticoid copepods increased greatly, comprising $23 \%$ of total numbers on 6 March. This decreased to only $4 \%$ on 12 March. As a specific example, the concentration of the benthic harpacticoid copepod Euterpina acutifrons was $85 \mathrm{~m}^{-3}$ on 6 March, then gradually declined to a low of $4 \mathrm{~m}^{-3}$ on 12 March.

Table 2. Water-column-integrated, net coefficients of exponential growth $(\mu-\mathrm{g})$ for phytoplankton at Stn 5

\begin{tabular}{|lc|}
\hline Date (2001) & Net growth \\
\hline $5 \mathrm{Mar}$ & 0.587 \\
$6 \mathrm{Mar}$ & 0.168 \\
$7 \mathrm{Mar}$ & 0.129 \\
$9 \mathrm{Mar}$ & 0.042 \\
$10 \mathrm{Mar}$ & -0.093 \\
$11 \mathrm{Mar}$ & 0.048 \\
$12 \mathrm{Mar}$ & -0.106 \\
$13 \mathrm{Mar}$ & -0.092 \\
\hline
\end{tabular}

\section{DISCUSSION}

The strong winds of 5 to 6 March caused significant suspension of bottom materials in Florida Bay. Although there was a lag between the strongest winds on 5 and 6 March and the maximum SPM concentrations and highest light-extinction coefficients on $7 \mathrm{March}$, there were indications in the light data that suspension of bottom sediments had begun on 5 March. The light profile of 5 March showed an increasing light-extinction coefficient with increasing depth, suggesting an increased SPM concentration with depth. We believe that the time-lag between the strongest winds and the highest SPM concentrations can be attributed to there being some time required for the wind to mix the water sufficiently to suspend bottom sediments throughout the water column. After the highest SPM concentrations were seen on 7 March, suspended sediments gradually settled over the next several days as wind speeds declined. Associated with this suspension event, we observed strong increases in $\mathrm{NH}_{4}$ and $\mathrm{PO}_{4}$, weaker increases in $\mathrm{NO}_{3}+\mathrm{NO}_{2}$ and $\mathrm{Si}(\mathrm{OH})_{4}$, a decrease in microzooplankton abundance, and an increase in benthic copepods in the water column. These increases were followed by a decrease in SPM to pre-event levels at our study site by 10 March, an even quicker decline in $\mathrm{PO}_{4}$ concentration, gradual declines in $\mathrm{NH}_{4}$ and $\mathrm{Si}(\mathrm{OH})_{4}$ such that minima were attained at the end of our study, an increase in chl a stock in the late part of our study, an increase in phytoplankton productivity, an increase in microzooplankton grazing rate, and a settling of the benthic harpacticoid community. No grazing response was apparent in the mesozooplankton community. The wind event clearly injected dissolved and particulate benthic materials into the water column, where they directly stimulated the bacterioplankton, phytoplankton, and microzooplankton communities within 1 to $2 \mathrm{~d}$ after the event. Heterotrophy dominated the water column at this time. The stimulation of the pelagic food web continued until the completion of our study $6 \mathrm{~d}$ after the event. By the end of the study, the water column was net autotrophic.

Chl a data from our primary station indicated that there was no immediate response of phytoplankton biomass to the wind event, suggesting that benthic phytoplankton did not contribute significantly to the pelagic environment during this study. Benthic chl a may make a significant contribution to the water column in early-winter mixing events if benthic phytoplankton accumulate over the summer, but this contribution should diminish with subsequent mixing events. The high frequency of resuspension events in the winter in Florida Bay, combined with the high 
light-extinction coefficients, does not allow sufficient time for re-establishment of benthic phytoplankton biomass.

SPM concentration and light extinction at our primary study site began to recover about $5 \mathrm{~d}$ before our study ended. However, light extinction did not return to pre-event levels, whereas SPM concentrations did. The reasons for this are unclear. It did not appear that phytoplankton contributed more to light extinction in the latter half of our study than at the onset, because $\mathrm{chl}$ a concentrations did not increase until the last day of our study. It is possible that chromophoric dissolved organic matter (CDOM) was injected into the water column during the mixing event. This may have contributed to light extinction after SPM had settled.

Nutrient concentrations within Florida Bay are highly variable both spatially and temporally (Fourqurean et al. 1993, Phlips et al. 1999, Tomas et al. 1999). Fourqurean et al. (1993) concluded that $P$ is generally the limiting macronutrient in Florida Bay. However, the major source of $\mathrm{P}$ in the bay is from the Gulf of Mexico to the west. Phlips et al. (1999) suggested that $\mathrm{P}$ was most likely to be limiting in the eastern bay, and Tomas et al. (1999) showed that phytoplankton populations in the western bay were consistently $\mathrm{N}$ limited and P limitation was common in the central and eastern bay. The potential significance of resuspension events to nutrient and phytoplankton dynamics was mentioned in all 3 studies (Fourqurean et al. 1993, Phlips et al. 1999, Tomas et al. 1999) but no data were presented. In other shallow, easily mixed environments, wind-induced suspension of sediments has been shown to supply nutrients to the water column (Vidal 1994, Pederson et al. 1995, Morin \& Morse 1999).

In our study, the wind event dramatically increased levels of $\mathrm{PO}_{4}$ in the water column, indicating delivery from the benthos. Pre-event $\mathrm{PO}_{4}$ concentrations were low and concentrations returned to similar levels within a few days after the event, possibly through phytoplankton uptake. However, concentrations of $\mathrm{PO}_{4}$ in Florida Bay are generally low, because of adsorption onto the calcium carbonate particles that dominate Florida Bay sediments (de Kanel \& Morse 1978, Short 1987, Lapointe 1989, Millero et al. 2001), and it has been suggested that sequestering of $\mathrm{PO}_{4}$ by sediments explains $\mathrm{P}$ limitation in Florida Bay (Fourqurean et al. 1993). The enhanced concentration of $\mathrm{PO}_{4}$ observed during the mixing event may have originated from porewaters and partly from desorption from the suspended sediments. Exchange of $\mathrm{PO}_{4}$ between water and carbonate sediment is a rapid process in Florida Bay (Millero et al. 2001). Hansen et al. (1997) have shown that the suspension of sediments can act as a source of $\mathrm{PO}_{4}$. Regardless of the source,
$\mathrm{PO}_{4}$ concentrations in the water column increased dramatically in response to the wind event in our study.

$\mathrm{NH}_{4}$ concentration also increased significantly in response to the wind event and, as with $\mathrm{PO}_{4}$, highest concentrations were observed on 7 March. Pre-event concentration was already high however, and post-event decline was more gradual than for $\mathrm{PO}_{4}$. Suspension of sediments is known to play an important role in $\mathrm{NH}_{4}$ flux in other systems (Reddy et al. 1996, Sloth et al. 1996, Mortimer et al. 1998, Morin \& Morse 1999). Disturbance of interstitial waters is probably responsible for the dramatic increase in $\mathrm{NH}_{4}$ concentrations observed at the onset of the event. The post-event reduction may have been due to phytoplankton uptake (McCarthy 1980), or it may have been the result of an adsorption reaction with the suspended solids (Rosenfeld 1979).

$\mathrm{NO}_{3}+\mathrm{NO}_{2}$ concentration did not change much during the suspension event, although an approximate doubling was observed $1 \mathrm{~d}$ after the maxima in $\mathrm{NH}_{4}$ and $\mathrm{PO}_{4}$. Concentrations remained essentially unchanged throughout the post-event period until the last day of our study, indicating that there was no net use of $\mathrm{NO}_{3}$ $+\mathrm{NO}_{2}$ during this time and suggesting that there was no phytoplankton uptake of these $\mathrm{N}$ forms until the last day of our study, when $\mathrm{NH}_{4}$ concentration was low.

Pre-event concentration of $\mathrm{Si}(\mathrm{OH})_{4}$ was high, but the maximum observed during our study was associated with the mixing event, indicative of a benthic input associated with wind-mixing. With the exception of the last sampling day, concentration declined throughout the post-event period.

$\mathrm{N}: \mathrm{P}$ ratios between 40 and 140 have been found by other investigators in north-central and NE regions of Florida Bay, while the NW region typically has values closer to the Redfield ratio of 16:1 (Fourqurean et al. 1993, Lavrentyev et al. 1998). The N:P ratio in the surface water at our study site was $>31$ on all occasions, ranging between 31 and 119, suggesting that $\mathrm{P}$ may have been a limiting nutrient during our study. Estimation of nutrient limitation from the ratios of concentrations must be made with caution, however, because of unknown dynamics and turnovers within each nutrient pool. For example, the slope of the decline in $\mathrm{Si}(\mathrm{OH})_{4}$ from 8 to 13 March is $-3.54 \mu \mathrm{mol} \mathrm{d} \mathrm{d}^{-1}$ compared to $-1.21 \mu \mathrm{mol} \mathrm{d}{ }^{-1}$ for the $\mathrm{NH}_{4}$ decline over the same period. This drawdown ratio of nearly 3:1 for $\mathrm{Si}(\mathrm{OH})_{4}: \mathrm{NH}_{4}$ suggests that there was a significant $\mathrm{NH}_{4}$ regeneration during this time, even though the total concentration was declining. During the $3 \mathrm{~d}$ of most rapid $\mathrm{PO}_{4}$ drawdown ( 7 to $9 \mathrm{March}$ ), the slope of the $\mathrm{PO}_{4}$ decrease was $-0.097 \mu \mathrm{mol} \mathrm{d}{ }^{-1}$, yielding an $\mathrm{N}: \mathrm{P}$ drawdown ratio of 12:1, further suggesting a significant $\mathrm{NH}_{4}$ regeneration during this time. Confounding these types of calculations is the high probability of a significant non-biological alteration of $\mathrm{PO}_{4}$ concentration. 
Direct evidence from our dilution experiments suggested that phytoplankton growth was nutrient-limited immediately prior to the wind event (5 March), but from 6 March until the end of our study on 13 March the degree of nutrient limitation was small or negligible. Nutrients were clearly being drawn down over this post-wind-event period, especially $\mathrm{NH}_{4}, \mathrm{PO}_{4}$ and $\mathrm{Si}(\mathrm{OH})_{4}$, but the degree of limitation, if any, did not appear to change significantly during this time. Wind events such as we observed significantly alter the concentrations and ratios of dissolved nutrients on short timescales, and in our study the wind event appeared to reduce nutrient limitation for the duration of our study period.

After the mixing event was initiated on 6 March, light availability was the dominant factor affecting phytoplankton growth and production. Our data show how severely light extinction increased during the mixing event. Light has been suggested as a potential limitation to phytoplankton production in Florida Bay (Phlips et al. 1995). In that study, mixed-layer irradiance frequently fell within or near the threshold used to describe the onset of light limitation. Moreover, Phlips et al. (1995) found that values of mixed-layer irradiance were typically lower in the windy season (from late fall to early spring) than during the summer. Philps et al. (1999) conducted a survey across Florida Bay and found that the ratio of chl a concentration to phytoplankton biovolume ( $\mu \mathrm{g}$ chl a $\mathrm{mm}^{-3}$ cellular biovolume), an indicator of light adaptation of phytoplankton, is highest in the western region of Florida Bay, suggesting adaptation to low-light conditions. Kelble (2003) also found that light limitation was strongest in the western part of Florida Bay. Throughout our study, there was a single relationship between productivity per $\mathrm{mg} \mathrm{chl} a$ and light intensity. The wide range in light extinction observed during our study meant that daily productivity ranged accordingly. For example, the depth of the $1 \%$ light level varied from about $0.4 \mathrm{~m}$ on 7 and 8 March during the highest concentration of SPM to nearly $1.5 \mathrm{~m}$ at the end of our study on 12 and 13 March. Gross productivity was $0.226 \mathrm{mmol} \mathrm{O}_{2} \mathrm{~m}^{-2} \mathrm{~h}^{-1} \mathrm{mg}^{-1} \mathrm{chl}$ a on 8 March and almost 5 times higher $\left(1.018 \quad \mathrm{mmolO}_{2} \quad \mathrm{~m}^{-2} \quad \mathrm{~h}^{-1}\right.$ $\mathrm{mg}^{-1} \mathrm{chl}$ a) on 12 March, a difference entirely attributable to the improved light environment. As the suspended sediment settled, the decrease in light extinction allowed more of the water-column chl a (which was homogenously distributed) to receive light, increasing the integrated production.

With the exception of 7 March, the instantaneous growth rate of phytoplankton $(\mu)$ measured in the dilution experiments was consistently high because incubation bottles were deployed just below the surface and received adequate light for high growth. Based on these few data points, we derived a relationship between $\mu$ and light intensity in order to estimate a water-column net growth rate for the phytoplankton community. These rates were low or slightly negative from the time the suspension event began on 6 March until our study ended, consistent with the lack of observed changes in chl a concentration, except for the last day, when observed chl a concentration increased. It should be noted that interpretation of results from bottle incubations during periods of high SPM concentration requires caution. SPM settled in our bottles in spite of high levels of incubator motion associated with wave action. This changed the light environment within the bottles and had unknown effects on the growth and grazing rates within the bottles during incubation.

Microzooplankton abundance decreased significantly from 5 to 7 March, when numbers were the lowest of our study. This is consistent with the decrease in microzooplankton grazing from 5 to 7 March and with the lowest observed microzooplankton grazing rate observed on 7 March, when SPM concentration was highest. The process by which the wind event led to a decrease in microzooplankton abundance (and grazing) is unclear, but the abundance decline was primarily due to ciliates, so the grazing reduction probably operated via this group of organisms. Ciliate populations did not recover during our study. Ciliates were also adversely affected by resuspension events studied in small microcosms in the southern Baltic Sea (Garstecki et al. 2002). After 7 March, microzooplankton grazing increased each day from 9 to 12 March. Associated with this there was a general increase in microzooplankton abundance, mostly thecate dinoflagellates.

Water-column respiration was approximately twice as high during the initial days of the suspension event as on all subsequent days. The water column was strongly net-heterotrophic at that time. The suspension event may have injected dissolved organic matter from pore waters into the water column, which stimulated bacterial activity for a few days. By the end of the study, autotrophy dominated water-column metabolism. This was the only time we observed a significant increase in chl a concentration.

Mesozooplankton grazing did not have a significant impact on phytoplankton populations at any time during our study. This is consistent with earlier work in Florida Bay (R. Brenner unpubl.) showing the dominance of microzooplankton grazing as a source of phytoplankton mortality. A numerical response in the mesozooplankton may occur over a longer time period if fluctuating food resources (phytoplankton and microzooplankton) affect reproduction and recruitment in mesozooplankton populations. Kleppel et al. 
(1998) found that copepods in Florida Bay may acquire as much as $70 \%$ of their dietary carbon from microzooplankton. There was a change in community composition of the mesozooplankton due to the resuspension of benthic copepods on 7 March. These gradually declined throughout the study and had returned to preevent concentrations by 11 and 12 March.

Although we have documented the significance of a single mixing event, the importance of such events to the annual productivity and trophic processes of Florida Bay is unclear. Wind events occur every 4 to $7 \mathrm{~d}$ during the winter season, so processes similar to those observed in this study will occur many times during an annual cycle. However, each event is unlikely to elicit the same response in the pelagic environment because of other factors. For example, the magnitude of the wind event will affect the amount and duration of particulate resuspension, and the effects of the light environment will vary accordingly. The timing of events is also important, because there has to be a period of several days of quiescence after each event for the system to utilize the stimulus provided by the event. If the period is too short, the post-event processes we describe here will be truncated, whereas if the period is too long, the system may decline to nutrient-limited conditions. In addition, each suspension event may diminish the potential inputs for the following event. Thus, although there are wind events passing through the area at frequent intervals throughout the winter each year, it is difficult to generalize and therefore difficult to extrapolate from one event to an annual impact on the system. It is clear, however, that wind events stimulate the multiple re-use and recycling of materials that enter the bay from external sources, and that responses to these events are rapid.

Acknowledgements. We gratefully acknowledge the cooperation and assistance of L. Givens and the Everglades National Park for providing use of the laboratory houseboat. The assistance of G. Berbarian and J. Zhang, NOAA/AOML/OCD, with oxygen analyses and nutrient analyses is greatly appreciated. Support for this project was provided by NOAA's South Florida Ecosystem Research and Monitoring Program under Grant NA06OP0521 to M.J.D. and S.R.C.

\section{LITERATURE CITED}

Calbet A, Landry MR (1999) Mesozooplankton influences on the microbial food web: direct and indirect trophic interactions in the oligotrophic open ocean. Limnol Oceanogr 44:1370-1380

Dagg MJ (1983) A method for the determination of copepod feeding rates during short time intervals. Mar Biol 75: 63-67

Dagg MJ (1988) Physical and biological responses to the passage of a winter storm in the coastal and inner shelf waters of the northern Gulf of Mexico. Cont Shelf Res 8:167-178
deKanel J, Morse JW (1978) The chemistry of orthophosphate uptake from seawater onto calcite and argonite. Geochim Cosmochim Acta 42:1335-1340

Fanning KA, Carder KL, Betzer PR (1982) Sediment resuspension by coastal waters: a potential mechanism for nutrient recycling on the ocean's margins. Deep-Sea Res 29: 953-965

Fourqurean JW, Jones RD, Zieman JC (1993) Processes influencing water column nutrient characteristics and phosphorus limitation of phytoplankton biomass in Florida Bay, FL, USA: inferences from spatial distributions. Estuar Coast Shelf Sci 36:295-314

Franks PJS (2001) Phytoplankton blooms in a fluctuating environment: the roles of plankton response time scales and grazing. J Plankton Res 23:1433-1441

Friederich GE, Codispoti LA, Sakamoto CM (1991) An easyto-construct Winkler titration system. Techn Rep 91-6. Monterey Bay Aquarium Research Institute, Monterey Bay, CA

Frost BW (1972) Effects of size and concentration of food particles on the feeding behavior of the marine planktonic copepod Calanus pacificus. Limnol Oceanogr 17:205-215

Garstecki T, Wickham SA, Arndt H (2002) Effects of experimental sediment resuspension on a coastal planktonic microbial food web. Estuar Coast Shelf Sci 55:751-762

Hansen PJ (1992) Prey size selection, feeding rates and growth dynamics of heterotrophic dinoflagellates with special emphasis on Gyrodinium spirale. Mar Biol 114: 327-334

Hansen PS, Phlips EJ, Aldridge FJ (1997) The effects of sediment resuspension on phosphorus available for algal growth in a shallow subtropical lake, Lake Okeechobee. Lake Reservoir Manag 13:154-159

Kelble C (2003) Attenuation of photosynthetically active radiation (PAR) in Florida Bay, USA. MS thesis, University of Miami

Kelly JR, Berounsky VM, Nixon SW, Oviatt CA (1985) Benthic-pelagic coupling and nutrient cycling across an experimental eutrophication gradient. Mar Ecol Prog Ser 26:207-219

Kiørboe T (1993) Turbulence, phytoplankton cell size, and the structure of pelagic food webs. Adv Mar Biol 29:1-72

Kleppel GS, Burkart CA, Tomas C (1998) Egg production of the copepod Acartia tonsa in Florida Bay during summer. 1. The roles of food environment and diet. Estuaries 21: 328-339

Landry MR, Hassett RP (1982) Estimating the grazing impact of marine micro-zooplankton. Mar Biol 67:283-288

Lapointe BE (1989) Macroalgal production and nutrient relations in oligotrophic areas of Florida Bay. Bull Mar Sci 44: 313-323

Lavrentyev PJ, Bootsma HA, Johengen TH, Cavaletto JF, Gardner WS (1998) Microbial plankton response to resource limitation: insights from the community structure and seston stoichiometry in Florida Bay, USA. Mar Ecol Prog Ser 165:45-57

Lehman JT (1980) Release and cycling of nutrients between planktonic algae and herbivores. Limnol Oceanogr 25: 620-632

Marcus NH, Boero F (1998) Minireview: the importance of benthic-pelagic coupling and the forgotten role of life cycles in coastal aquatic systems. Limnol Oceanogr 43: $763-768$

McCarthy JJ (1980) Nitrogen. In: Morris I (ed) The physiological ecology of phytoplankton. University of California Press, Berkeley, p 191-234

Millero FJ, Hiscock WT, Huang F, Roche M, Zhang JZ (2001) 
Seasonal variation of the carbonate system in Florida Bay. Bull Mar Sci 68:101-123

Morin J, Morse JW (1999) Ammonium release from resuspended sediments in the Laguna Madre estuary. Mar Chem 65:97-110

Mortimer RJG, Krom MD, Watson PG, Frickers PE, Davey JT, Clifton RJ (1998) Sediment-water exchange of nutrients in the intertidal zone of the Humber estuary, UK. Mar Pollut Bull 37:261-279

Nielson TG, Kiørboe T (1991) Effects of a storm event on the structure of the pelagic food web with special emphasis on planktonic ciliates. J Plankton Res 13:35-51

Nixon SW (1981) Remineralization and nutrient cycling in coastal marine ecosystems. In: Neilson BJ, Cronin LE (eds) Estuaries and nutrients. Humana, Clifton, NJ

Pederson OB, Christiansen C, Laursen MB (1995) Windinduced long term increase and short term fluctuations of shallow water suspended matter and nutrient concentrations, Ringkoebing Fjord, Denmark. Ophelia 41:273-287

Phlips EJ, Badylak S (1996) Spatial variability in phytoplankton standing crop and composition in a shallow inner-shelf lagoon, Florida Bay, Florida. Bull Mar Sci 58:203-216

Phlips EJ, Lynch TC, Badylak S (1995) Chlorophyll $a$, tripton, color, and light availability in a shallow tropical inner-shelf lagoon, Florida Bay, USA. Mar Ecol Prog Ser 127:223-234

Phlips EJ, Badylak S, Lynch TC (1999) Blooms of the picoplanktonic cyanobacterium Synechococcus in Florida Bay, a subtropical inner-shelf lagoon. Limnol Oceanogr 44:1166-1175

Platt T, Gallegos C, Matlick H (1980) Photoinhibition of photosynthesis in natural assemblages of marine phytoplankton. J Mar Res 38:687-701

Reddy KR, Fisher MM, Ivanoff D (1996) Resuspension and diffusive flux of nitrogen and phosphorus in a hypereutrophic lake. J Environ Qual 25:363-371

Rosenfeld JK (1979) Ammonium adsorption in nearshore anoxic sediments. Limnol Oceanogr 24:356-364

Shoef WT, Lium BW (1976) Improved extraction of chlorophyll $a$ and $b$ from algae using dimethylsulfoxide. Limnol Oceanogr 21:926-928

Short FT (1987) Effects of sediment nutrients on seagrasses: literature review and mesocosm experiments. Aquat Bot 27:41-57

Sloth NP, Riemann B, Nielsen LP, Blackburn TH (1996) Resilience of pelagic and benthic microbial communities to sediment resuspension in a coastal ecosystem, Knebel

Editorial responsibility: Otto Kinne (Editor),

Oldendorf/Luhe, Germany
Vig, Denmark. Estuar Coast Shelf Sci 42:405-415

Strickland JDH, Parsons TR (1972) A practical handbook of seawater analysis, 2nd edn. Bull Fish Res Board Can 167:21-26

Stumm W, Leckie JO (1971) Phosphate exchange with sediments: its role in productivity in surface waters. In: Jenkins SH (ed) Advances in water pollution research, Vol 2, III. Pergamon Press, Malden, MA, p 26/1-26/16

Tomas CR, Bendis B, Johns K (1999) Role of nutrients in regulating plankton blooms in Florida Bay. In: Kumpf H, Steidinger K, Sherman K (eds) The Gulf of Mexico Large Marine Ecosystem. Blackwell, Oxford, p 323-337

Vidal M (1994) Phosphate dynamics tied to sediment disturbances in Alfacs Bay (NW Mediterranean). Mar Ecol Prog Ser 110:211-221

Wang JD (1998) Subtidal flow patterns in western Florida Bay. Estuar Coast Shelf Sci 46:901-915

Wang JD, Kreeke J, Krishnan N, Smith D (1994) Wind and tide response in Florida Bay. Bull Mar Sci 54:579-601

Warnken KW, Gill GA, Santschi PH, Griffin LL (2000) Benthic exchange of nutrients in Galveston Bay, Texas. Estuaries 23:647-661

Zhang JZ, Berberian GA (1997) Determination of dissolved silicate in estuarine and coastal waters by gas segmented continuous flow colorimetric analysis. In: Methods for the determination of chemical substances in marine and estuarine environmental matrices, 2nd edn. EPA/ 600/R-97/072. US Environmental Protection Agency, Washington, DC, p 366.0-1-366.0-2

Zhang JZ, Ortner PB, Fischer C, Moore L (1997a) Determination of ammonia in estuarine and coastal waters by gas segmented continuous flow colorimetric analysis. In: Methods for the determination of chemical substances in marine and estuarine environmental matrices, 2nd edn. EPA/600/R-97/072. US Environmental Protection Agency, Washington, DC, p 349.0-1-349.0-2

Zhang JZ, Ortner PB, Fischer C (1997b) Determination of nitrite and nitrate in estuarine and coastal waters by gas segmented continuous flow colorimetric analysis. In: Methods for the determination of chemical substances in marine and estuarine environmental matrices, 2nd edn. EPA/600/R-97/072. US Environmental Protection Agency, Washington, DC, p 353.4-1-353.4-2

Zhang JZ, Fischer C, Ortner PB (1999) Optimization of performance and minimization of silicate interference in continuous flow phosphate analysis. Talanta 49:293-304

Submitted: April 15, 2003; Accepted: September 16, 2003

Proofs received from author(s): January 21, 2004 